\section{BRAZIULIAN JOURNAL \\ OF MEDICAL AND BIOLOGICAL RLSF.ARCH}

www.bjournal.com.br
ISSN 0100-879X

Volume 42 (12) 1119-1247 December 2009

BIOMEDICAL SCIENCES

AND

CLINICAL INVESTIGATION

Braz J Med Biol Res, December 2009, Volume 42(12) 1173-1178

Effect of curcumin on the proliferation and apoptosis of hepatic stellate cells

J.C. Shu, Y.J. He, X. Lv, J.R. Zhao, J. Zhao, Y. Shen, G.R. Ye and L.X. Wang

The Brazilian Journal of Medical and Biological Research is partially financed by
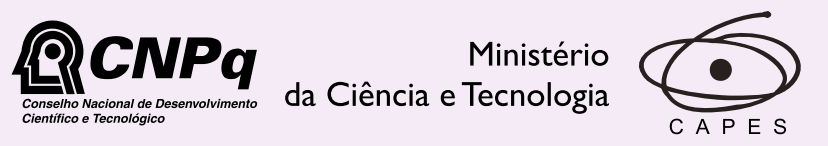

Ministério da Educação

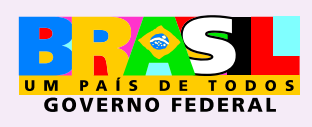

DFAPESP

Institutional Sponsors 


\title{
Effect of curcumin on the proliferation and apoptosis of hepatic stellate cells
}

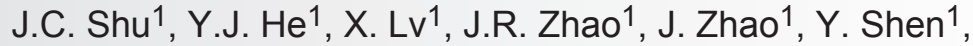 \\ G.R. Ye ${ }^{1}$ and L.X. Wang ${ }^{2}$
}

${ }^{1}$ Department of Gastroenterology, Guangzhou Red Cross Hospital, Jinan University, Guangzhou, China

${ }^{2}$ School of Biomedical Sciences, Charles Sturt University, Wagga Wagga, Australia

\begin{abstract}
This study was designed to investigate the effect of curcumin (diferuloylmethane) on the proliferation and apoptosis of hepatic stellate cells (HSC). The cell line HSC-T6 $\left(1.25 \times 10^{5} \mathrm{cells} / \mathrm{mL}\right)$ was incubated with curcumin and HSC proliferation was detected by a methyl thiazolyl tetrazolium colorimetric assay. HSC apoptosis was detected by flow cytometry, transmission electron microscope and agarose gel electrophoresis. HSC proliferation was significantly inhibited in a concentration-dependent manner (10.6 to $63.5 \%$ ) after incubation with $20-100 \mu \mathrm{M}$ curcumin, compared with a control group. At 20, 40, and $60 \mu \mathrm{M}$, after $24 \mathrm{~h}$ of incubation, curcumin was associated with a significant increase in the number of HSC in the G2/M phase, and a significant decrease in cell numbers in the $S$ phase $(P<0.05)$. At these concentrations, curcumin was also associated with an increase in the apoptosis index of $15.3 \pm 1.9,26.7 \pm 2.8$, and $37.6 \pm 4.4 \%$, respectively, compared to control $(1.9 \pm 0.6 \%, P<0.01)$. At $40 \mu \mathrm{M}$, the curcumin-induced apoptosis index at $12,24,36$, and $48 \mathrm{~h}$ of incubation was $12.0 \pm 2.4,26.7 \pm 3.5,33.8 \pm 1.8$, and $49.3 \pm 1.6 \%$, respectively $(P<0.01)$. In conclusion, curcumin inhibits the in vitro proliferation of HSCs in the G2/M phase of the cell cycle and also induces apoptosis in a concentration- and time-dependent manner. The in vivo effect of curcumin on HSCs requires further investigation.
\end{abstract}

Key words: Curcumin; Hepatic stellate cells; Proliferation; Apoptosis; Hepatic fibrosis

\section{Introduction}

Hepatic fibrosis is a reversible complication of advanced liver disease and represents a major worldwide health care burden. Hepatic stellate cells (HSC) undergo activation into proliferative and fibrogenic myofibroblast-like cells during liver injury (1). The imbalance between proliferation and apoptosis of HSC is the main pathogenesis of liver fibrosis $(1,2)$. Therefore, inhibiting HSC activation and inducing apoptosis may be useful strategies to prevent or treat hepatic fibrosis (3).

Curcumin, also known as turmeric yellow or diferuloylmethane, is a phenol derived from the herb Curcuma aromatica salisb (4). The chemical structure of curcumin is 1,6-heptadiene-3,5-dione and its molecular weight is 368 . For several decades curcumin has been widely used as a food coloring ingredient for its yellowish color. In the last 10 years, several in vitro and in vivo studies have reported that curcumin possesses significant pharmacological actions, such as anti-tumor effects, anti-inflammatory effects and induction of apoptosis of cancer cells (5-10).

The effects of curcumin on HSC and hepatic fibrosis are unknown. The primary aim of the present study was to determine the effects of curcumin on the proliferation and apoptosis of an HSC line in vitro.

\section{Material and Methods}

The rat hepatic stellate cell line HSC-T6, with SV40 transfection showing an activated phenotype (11), was a generous gift from Professor Lie-Ming Xu (Division of Liver Diseases, Shanghai University of TCM, Shanghai, China). Curcumin and methyl thiazolyl tetrazolium (MTT) were purchased from Sigma-Aldrich Company (USA); newborn calf serum and Dulbecco's modified Eagle's medium (DMEM) were purchased from Hyclone, Gibco (USA). A200-bp DNA marker was obtained from the Sino-American Biotechnology Company (China).

Correspondence: L.X. Wang, School of Biomedical Sciences, Charles Sturt University, Wagga Wagga, NSW 2678, Australia. Fax: +61-2-69-33-2587. E-mail: Iwang@csu.edu.au or J.C. Shu, Department of Gastroenterology, Guangzhou Red Cross Hospital, Jinan University, No. 396, Tong Fu Zhong Lu, Guangzhou 510220, China. Fax: +86-020-3440-3835. E-mail: shujc62@hotmail.com 


\section{Preparation of the curcumin stock solution}

Curcumin was dissolved in a small volume of dimethyl sulfoxide (DMSO, equivalent to $<1 \%$ of the final volume). The DMSO curcumin solution was mixed rapidly with DMEM to provide a solution of $10 \mathrm{mM}$ curcumin. The solution was filtered through a $0.22-\mu \mathrm{m}$ membrane. Aliquots were stored at $-20^{\circ} \mathrm{C}$ protected from light.

\section{HSC-T6 culture}

Cells were cultured in DMEM, supplemented with 100 $\mathrm{U} / \mathrm{mL}$ penicillin, $100 \mathrm{U} / \mathrm{mL}$ streptomycin and $10 \%$ newborn calf serum. Cells were incubated in a cell culture flask at $37^{\circ} \mathrm{C}$ under $5 \% \mathrm{CO}_{2}, 95 \%$ air and saturated humidity and the medium was changed every 2 days. Cells were digested with $0.25 \%$ trypsin and $0.02 \%$ EDTA when the cell density reached 80 to $90 \%$.

\section{Effect of curcumin on cell proliferation}

The effect of curcumin on HSC proliferation was monitored with MTT. The cell concentration of the logarithmic growth phase was adjusted to $1 \times 105 / \mathrm{mL}$ and $100 \mu \mathrm{L}$ aliquots were transferred to a 96-well plate. Serum-free DMEM was added to each well after $24 \mathrm{~h}$ and incubated for $24 \mathrm{~h}$ in order to synchronize cells to the resting stage. The supernatant was removed and $0,20,40,80,100 \mu \mathrm{M}$ curcumin containing DMEM and $2 \%$ serum were added and co-cultured for $24 \mathrm{~h}$. This was repeated five times in each concentration group. The supernatant was removed and $10 \mu \mathrm{L}$ MTT and 100 $\mu \mathrm{L}$ serum were added to each well and cultured for 4 $\mathrm{h}$. The culture solution was removed and the remaining cells were dissolved with $100 \mu \mathrm{L}$ DMSO. Absorbance was measured with an ELISA Reader (Tosoh, Japan) with a 630-nm reference wavelength. Inhibition ratio $=$ 1 - (absorbance of drug group / absorbance of control group) x $100 \%$.

\section{Flow cytometry test for apoptosis}

Cells in the logarithmic growth phase were seeded into T-25 culture flasks containing medium at $7 \times 10^{5} / \mathrm{mL}$ and incubated for $24 \mathrm{~h}$. The medium was removed and serum-free DMEM was added to T-25 culture flasks and incubated for $24 \mathrm{~h}$. The medium was removed and 0,10 , 20,40 , or $60 \mu \mathrm{M}$ curcumin were added and incubated for $24 \mathrm{~h}$. In an additional set of experiments, $40 \mu \mathrm{M}$ curcumin was added and cells were cultured for 12, 24, 36, and $48 \mathrm{~h}$, respectively. Suspended and adherent cells were collected and washed once with cold phosphatebuffered saline (PBS). Cells were then fixed with $70 \%$ alcohol and a single cell suspension was prepared and stored at $4^{\circ} \mathrm{C}$. The fixation fluid was washed with PBS before the test. Twenty microliters RNase A was added and incubated for $30 \mathrm{~min}$ at $37^{\circ} \mathrm{C}$ and $800 \mu \mathrm{L}$ propidium iodide staining solution was added for overnight staining at $4^{\circ} \mathrm{C}$ away from light. Apoptosis was detected by flow cytometry (BD FACS Calibur, USA) and images were quantified using the ModFIT software to analyze the cell generation cycle and to calculate apoptosis index.

\section{Morphology of cell apoptosis}

Cells were co-cultured with $40 \mu \mathrm{M}$ curcumin for 24 h. Suspended and adherent cells were collected and washed once with PBS and then fixed with $2.5 \%$ glutaraldehyde at $4^{\circ} \mathrm{C}$ for $1 \mathrm{~h}$, and postfixed with $1 \%$ osmic acid for $30 \mathrm{~min}$. Cells were stained with lead-uranium and the ultrastructural organization was observed with a Hitachi-600 (Japan) transmission electron microscope.

\section{DNA ladder of the cell apoptosis test}

Cells were treated with $0,20,40$, or $60 \mu \mathrm{M}$ curcumin for $24 \mathrm{~h}$ and DNA was extracted as described previously (12); $1.5 \%$ agarose gel electrophoresis was performed for $3 \mathrm{~h}$ at constant voltage of 50 volts, and observed with a gel imaging system (Multi Genius Bio-Imaging System, Syngene, USA).

\section{Statistical analysis}

Data are reported as means \pm SD. Statistical differences were determined by one-way analysis of variance or the Student $t$-test. Differences were considered to be statistically significant at $P<0.05$.

\section{Results}

\section{Curcumin and HSC proliferation}

After treatment with curcumin, HSC proliferation was significantly reduced compared to control (Table 1). The inhibition rate increased with increasing curcumin concentrations $(P<0.01)$. The $50 \%$ inhibiting concentration $\left(\mathrm{IC}_{50}\right)$ was $89 \mu \mathrm{M}$, as computed by the Probit method.

\section{Effects of curcumin on the cell cycle}

As shown in Table 2, curcumin treatment at a con-

Table 1. Effect of curcumin on hepatic stellate cell proliferation.

\begin{tabular}{ccc}
\hline Concentration & Absorbance & Inhibition (\%) \\
\hline $0 \mu \mathrm{M}$ & $1.33 \pm 0.04$ & $0 \%$ \\
$20 \mu \mathrm{M}$ & $1.19 \pm 0.02^{*}$ & $10.6 \%$ \\
$40 \mu \mathrm{M}$ & $1.01 \pm 0.05^{*}$ & $24.2 \%$ \\
$60 \mu \mathrm{M}$ & $0.93 \pm 0.03^{*}$ & $30.1 \%$ \\
$80 \mu \mathrm{M}$ & $0.75 \pm 0.02^{*}$ & $43.9 \%$ \\
$100 \mu \mathrm{M}$ & $0.49 \pm 0.03^{*}$ & $63.5 \%$ \\
\hline
\end{tabular}

Data are reported as means \pm SD or percent. Cells were cultured in DMEM and incubated with curcumin for $24 \mathrm{~h}$ at $37^{\circ} \mathrm{C}$. Cell proliferation was measured by a methyl thiazolyl tetrazolium colorimetric assay. ${ }^{*} \mathrm{P}<0.05$ vs control group (Student $t$ - or chisquare tests). 
A

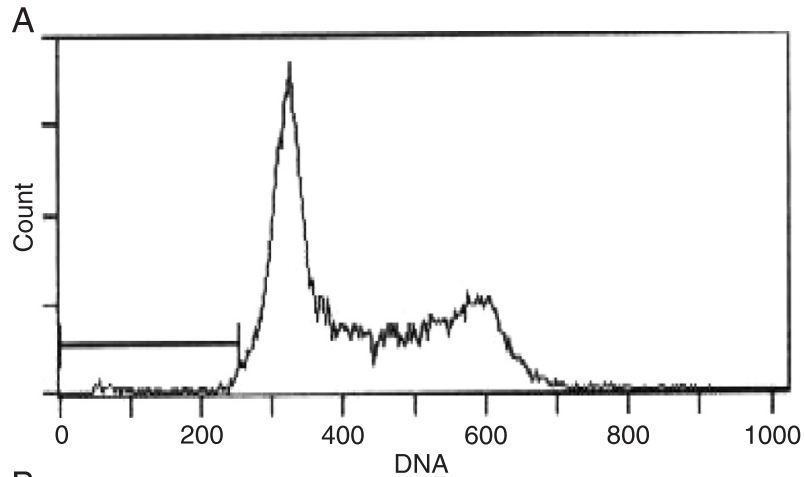

B

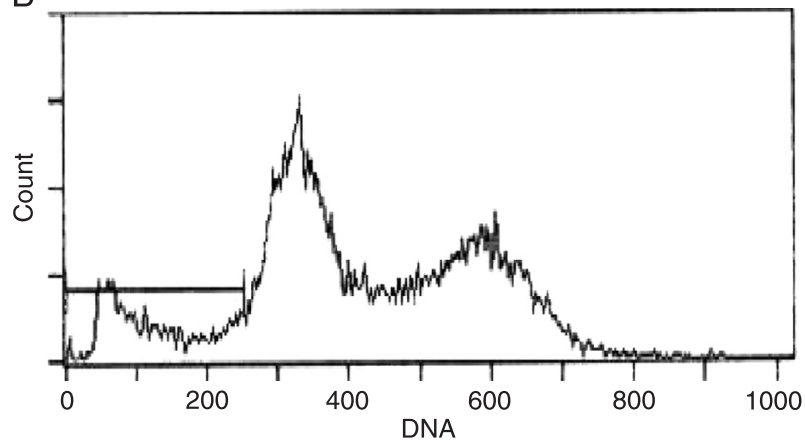

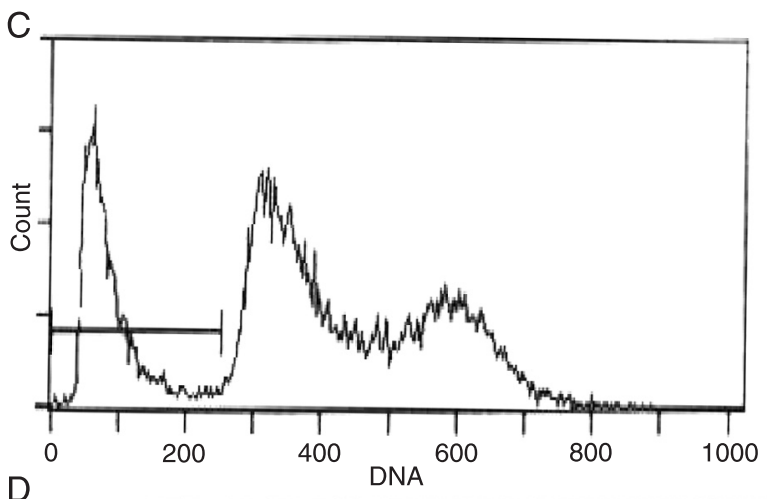

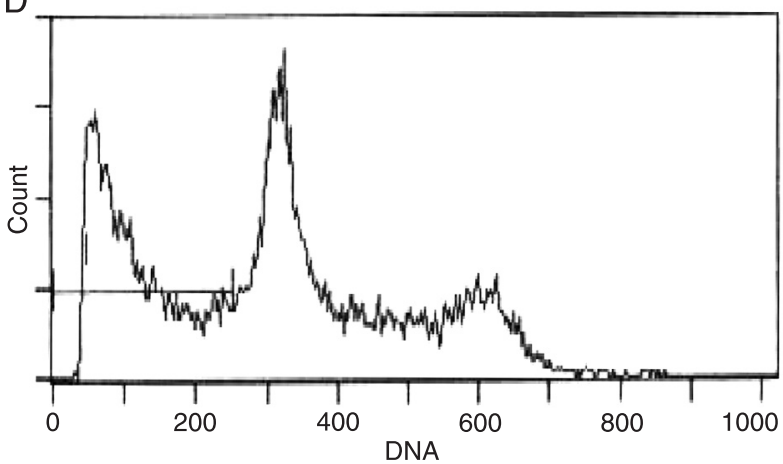

Figure 1. Flow cytometry hepatic stellate cell apoptosis before (control group, A), and after treatment with curcumin at 20 (B), 40 (C) and $60 \mu \mathrm{M}(\mathrm{D})$.

Table 2. Effects of curcumin on the cell cycle of hepatic stellate cells.

\begin{tabular}{lccc}
\hline Concentration & G0/G1 (\%) & \multicolumn{1}{c}{$\mathrm{S}(\%)$} & G2/M (\%) \\
\hline $0 \mu \mathrm{M}$ & $43.7 \pm 1.61$ & $50.3 \pm 1.51$ & $6.0 \pm 0.53$ \\
$10 \mu \mathrm{M}$ & $46.5 \pm 1.58$ & $46.9 \pm 1.18$ & $6.6 \pm 1.08$ \\
$20 \mu \mathrm{M}$ & $48.6 \pm 1.08$ & $43.6 \pm 0.92^{*}$ & $7.8 \pm 0.78^{*}$ \\
$40 \mu \mathrm{M}$ & $48.1 \pm 1.73$ & $33.0 \pm 0.64^{*}$ & $18.9 \pm 1.16^{*}$ \\
$60 \mu \mathrm{M}$ & $48.4 \pm 1.71$ & $30.4 \pm 1.28^{*}$ & $21.2 \pm 0.92^{*}$ \\
\hline
\end{tabular}

Data are reported in percent for the G0/G1, S and G2/M cell cycle phases. ${ }^{*} \mathrm{P}<0.05$ vs control group (Student $t$ - or chi-square tests).

centration of 10 to $60 \mu \mathrm{M}$ had no significant effect on the number of cells in the G0/G1 phase ( $P>0.05$ compared to control). As curcumin concentrations were increased from 10 to $60 \mu \mathrm{M}$, there was a gradual decrease in the number of cells in the $S$ phase, and a gradual increase in the cells in the $G 2 / M$ phase ( $P<0.05$ and 0.01 , respectively).

\section{Effects of curcumin on cell apoptosis}

A significant peak of hypodiploid cells indicative of apoptosis was detected by flow cytometry when HSC were incubated with curcumin at 20, 40, and $60 \mu \mathrm{M}$ (Figure 1), whereas the peak was not observed in the control group.

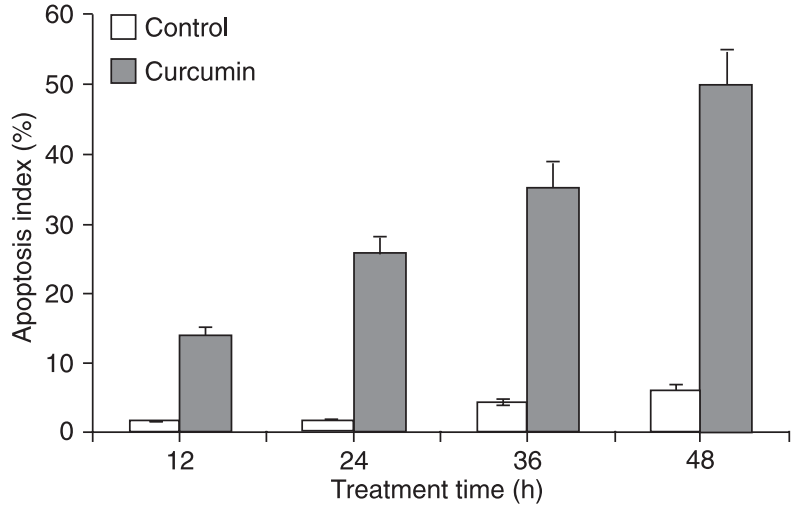

Figure 2. Comparison of the apoptosis index of hepatic stellate cells treated with $40 \mu \mathrm{M}$ curcumin for $12,24,36$ and $48 \mathrm{~h}$, respectively. Data are reported as means \pm SD for 5 experiments. Apoptotic index was defined as the number of apoptotic cells divided by the total number of cells, which was done by the ModFIT software.

The apoptosis indices of the curcumin groups were $15.3 \pm$ $1.88,26.7 \pm 2.79$, and $37.6 \pm 4.38 \%$, respectively, and they were higher than control rates $(1.9 \pm 0.64 \%, \mathrm{P}<0.01)$.

The HSC apoptosis index increased gradually with treatment time when HSC were treated with $40 \mu \mathrm{M}$ curcumin (Figure 2). 


\section{HSC morphology}

After incubation with $40 \mu \mathrm{M}$ curcumin for $24 \mathrm{~h}$, HSC became smaller when observed with the contrast phase microscope (Figure 3). Nuclear chromatin was condensed to a round shape along the inner part of the nuclear membrane. Condensed organelles and apoptotic bodies were observed by transmission electron microscope (Figure 4).

\section{DNA fragment detection}

A high molecular weight strip was found on the agarose gel of the control group (Figure 5) and a DNA ladder was detected after treatment with 20, 40, and 60 $\mu \mathrm{M}$ curcumin (Figure 5).

\section{Discussion}

The major findings of the present study were: 1) curcumin inhibits HSC proliferation in vitro in a concentration-dependent manner; 2) curcumin reduces the number of cells in the $S$ phase and increases the cells in the G2/M phase in a concentration-dependent manner; 3) curcumin induces HSC apoptosis in a concentration- and time-dependent manner.
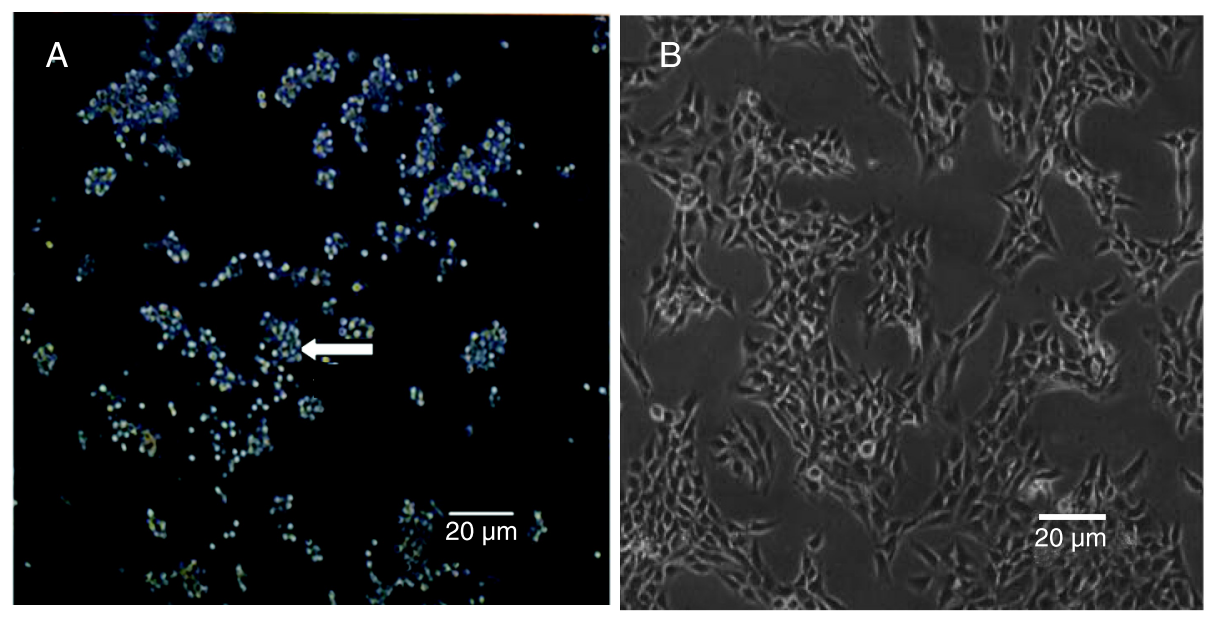

Figure 3. Effect of curcumin on the apoptosis of hepatic stellate cells examined with an inverted light microscope. A, Hepatic stelate cells incubated with $40 \mu \mathrm{M}$ curcumin for $24 \mathrm{~h}$. Arrow indicates apoptoic hepatic stellate cells. $B$, Control group.
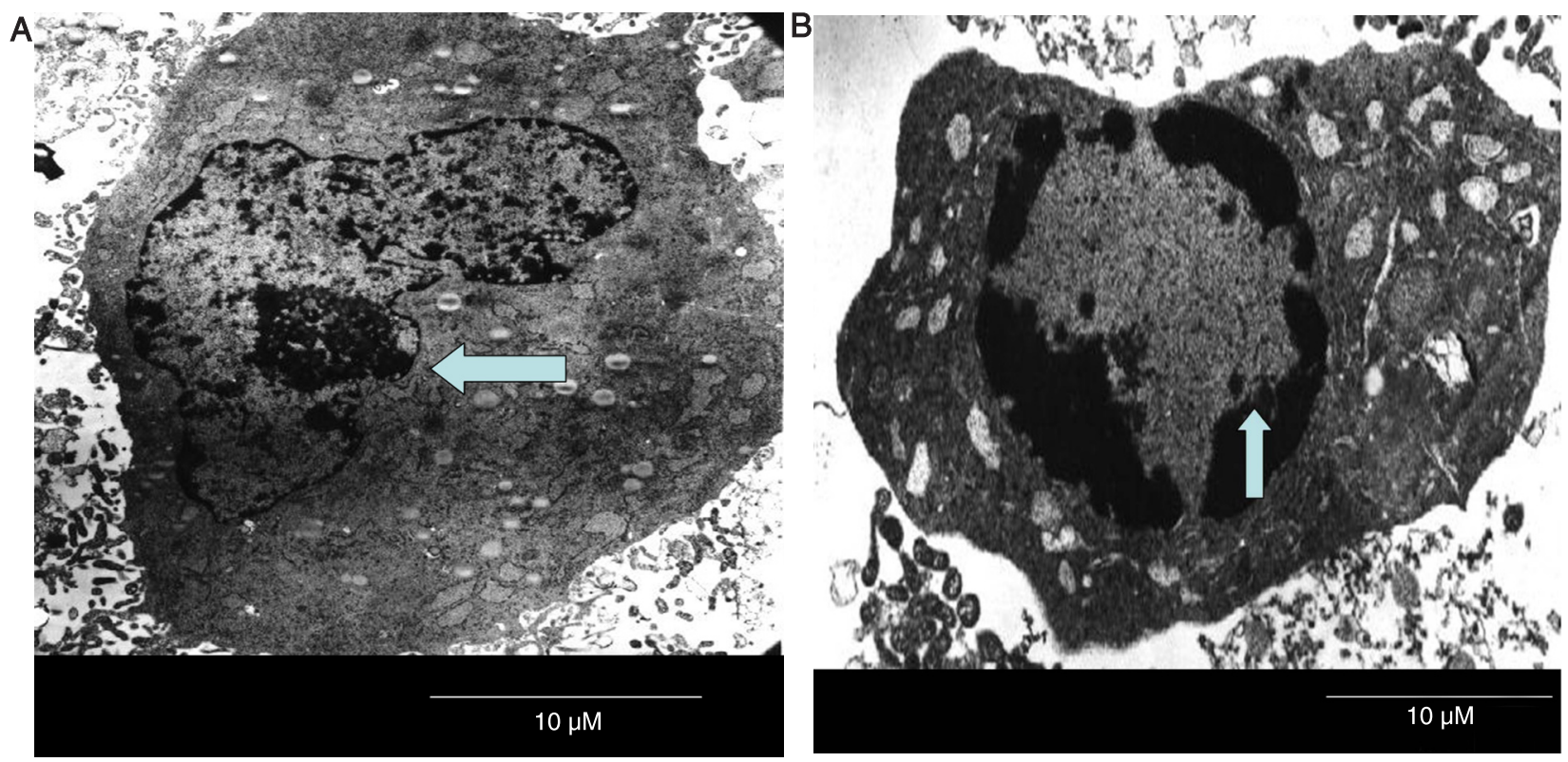

Figure 4. Effect of curcumin on the apoptosis of hepatic stellate cells (HSC) examined by electron microscopy (7000X). $A$, HSC and nuclear membrane were normal in the control group (arrow). B, HSC incubated with $40 \mu \mathrm{M}$ curcumin for $24 \mathrm{~h}$. Note that there was a significant cell shrinkage and chromatin condensation along the nuclear membrane (arrow). 


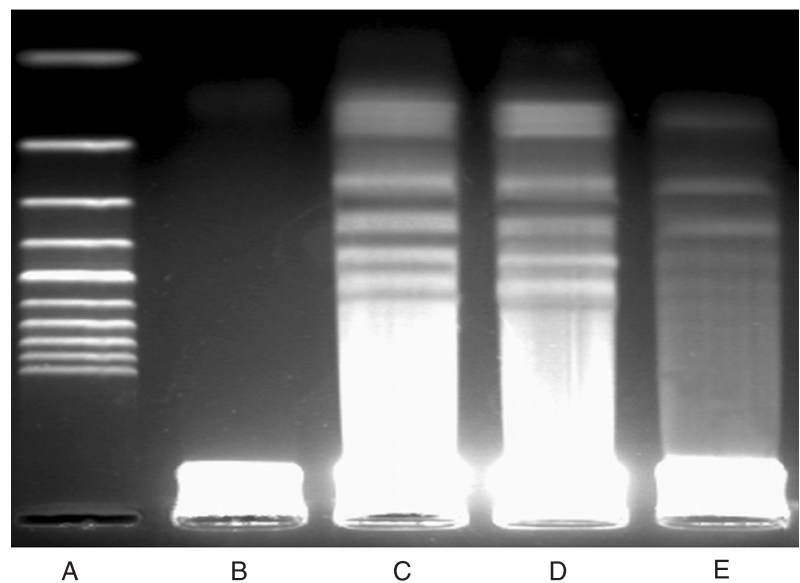

Figure 5. Detection of DNA fragmentation by agarose gel electrophoresis. Lane A, 200-bp DNA marker; lane B, control group; lane $C, 60 \mu \mathrm{M}$ curcumin; lane $D, 40 \mu \mathrm{M}$ curcumin; lane $E, 20 \mu \mathrm{M}$ curcumin.

Because of the critical role of HSC in the pathogenesis of hepatic fibrosis, induction of HSC apoptosis has become potentially important for the prevention or treatment of hepatic fibrosis. Enhanced HSC apoptosis may reduce the formation of procollagen and increase extracellular matrix degradation, aiding the recovery from hepatic fibrosis. Curcumin not only inhibits HSC proliferation in the S phase and induces apoptosis, but also inhibits the transformation of HSC from a quiescent phenotype to an activated phenotype, and decreases the expression of alpha-smooth muscle actin, a marker of HSC activation $(13,14)$. Curcumin also reduces the secretion of type I collagen in HSC in vitro,

\section{References}

1. Friedman SL. Hepatic stellate cells: protean, multifunctional, and enigmatic cells of the liver. Physiol Rev 2008; 88: 125172.

2. Gressner AM. The cell biology of liver fibrogenesis - an imbalance of proliferation, growth arrest and apoptosis of myofibroblasts. Cell Tissue Res 1998; 292: 447-452.

3. Friedman SL. Mechanisms of disease: Mechanisms of hepatic fibrosis and therapeutic implications. Nat Clin Pract Gastroenterol Hepatol 2004; 1: 98-105.

4. Adhikari S, Indira PK, Mukherjee T. Physico-chemical studies on the evaluation of the antioxidant activity of herbal extracts and active principles of some Indian medicinal plants. J Clin Biochem Nutr 2007; 40: 174-183.

5. Moragoda L, Jaszewski R, Majumdar AP. Curcumin induced modulation of cell cycle and apoptosis in gastric and colon cancer cells. Anticancer Res 2001; 21: 873-878.

6. Bush JA, Cheung KJ Jr, Li G. Curcumin induces apoptosis in human melanoma cells through a Fas receptor/caspase-8 pathway independent of p53. Exp Cell Res 2001; 271: 305314. and the collagen deposition in the liver of rats with hepatic fibrosis induced by carbon tetrachloride $(13,14)$. An earlier human study showed no significant side effects in a group of volunteers treated with $8 \mathrm{~g}$ curcumin per day for three months (15). These results suggest that curcumin may be safely used to treat hepatic fibrosis by several different mechanisms.

The signaling pathways by which curcumin affects cell proliferation and apoptosis are not entirely clear. In rat HSC, the inhibition of cell proliferation and induction of apoptosis appear to be related to the activation of peroxisome proliferator (16), a key regulator of the cell cycle and apoptosis. In Hodgkin's lymphoma cells, the effect of curcumin on the cells is associated with the inhibition of constitutively active NF-kappaB and STAT3 pathways, leading to a decreased expression of the proteins involved in cell proliferation and apoptosis, e.g., Bcl-2 and Bcl-xL (17). Also in Hodgkin's lymphoma cells, curcumin triggers apoptosis by activating caspase- 3 and caspase-9, and by changing nuclear morphology and phosphatidylserine translocation (17). In human acute myelogenous leukemia HL-60 cells, curcumin has also been found to induce apoptosis through the mitochondrial pathway involving caspase-8, BID cleavage, cytochrome c release, and caspase- 3 activation (7). It is uncertain how these signaling pathways or their interplay may have contributed to the significant effect of curcumin on cell growth and apoptosis in the present study. The precise signaling pathways leading to proliferation inhibition and apoptosis induction need to be further investigated.

We found that curcumin significantly inhibits proliferation and induces apoptosis of HSC in vitro. Further clinical studies are warranted to evaluate the safety and efficacy of this agent in the management of hepatic fibrosis.

7. Anto RJ, Mukhopadhyay A, Denning K, Aggarwal BB. Curcumin (diferuloylmethane) induces apoptosis through activation of caspase-8, BID cleavage and cytochrome c release: its suppression by ectopic expression of $\mathrm{Bcl}-2$ and Bcl-xl. Carcinogenesis 2002; 23: 143-150.

8. Dorai T, Gehani N, Katz A. Therapeutic potential of curcumin in human prostate cancer. II. Curcumin inhibits tyrosine kinase activity of epidermal growth factor receptor and depletes the protein. Mol Urol 2000; 4: 1-6.

9. Kim MS, Kang HJ, Moon A. Inhibition of invasion and induction of apoptosis by curcumin in H-ras-transformed MCF10A human breast epithelial cells. Arch Pharm Res 2001; 24: 349-354.

10. Sandur SK, Ichikawa H, Pandey MK, Kunnumakkara AB, Sung B, Sethi G, et al. Role of pro-oxidants and antioxidants in the anti-inflammatory and apoptotic effects of curcumin (diferuloylmethane). Free Radic Biol Med 2007; 43: 568580.

11. Vogel S, Piantedosi R, Frank J, Lalazar A, Rockey DC, Friedman SL, et al. An immortalized rat liver stellate cell 
line (HSC-T6): a new cell model for the study of retinoid metabolism in vitro. J Lipid Res 2000; 41: 882-893.

12. Pan MH, Chang WL, Lin-Shiau SY, Ho CT, Lin JK. Induction of apoptosis by garcinol and curcumin through cytochrome c release and activation of caspases in human leukemia HL-60 cells. J Agric Food Chem 2001; 49: 1464-1474.

13. Kang HC, Nan JX, Park PH, Kim JY, Lee SH, Woo SW, et al. Curcumin inhibits collagen synthesis and hepatic stellate cell activation in-vivo and in-vitro. J Pharm Pharmacol 2002; 54: 119-126.

14. Liu YG, Chen HC, Jiang YP. Experiment research of curcumin inhibit hepatic fibrosis. Shizhen Guoyi Guoyao 2002; 13: 273-275.
15. Aggarwal BB, Kumar A, Bharti AC. Anticancer potential of curcumin: preclinical and clinical studies. Anticancer Res 2003; 23: 363-398.

16. $\mathrm{Xu} \mathrm{J}, \mathrm{Fu} \mathrm{Y}, \mathrm{Chen} \mathrm{A}$. Activation of peroxisome proliferatoractivated receptor-gamma contributes to the inhibitory effects of curcumin on rat hepatic stellate cell growth. Am J Physiol Gastrointest Liver Physiol 2003; 285: G20-G30.

17. Mackenzie GG, Queisser N, Wolfson ML, Fraga CG, Adamo AM, Oteiza PI. Curcumin induces cell-arrest and apoptosis in association with the inhibition of constitutively active NFkappaB and STAT3 pathways in Hodgkin's lymphoma cells. Int J Cancer 2008; 123: 56-65. 